\title{
National Burden of Intestinal Parasites and Its \\ Determinants Among People Living with HIV/AIDS in Ethiopia: A Systematic Review and Meta-analysis
}

Tadesse Yirga Akalu ( $\square$ tadesseyirga680@gmail.com )

Debre Markos University https://orcid.org/0000-0002-5475-6183

Yared Asmare Aynalem

Debre Markos University

Wondimeneh Shibabaw Shiferaw

Debre Markos University

Yoseph Merkeb Alamneh

Debre Markos University

Asmamaw Getnet

Debre Markos University

Abtie Abebaw

Debre Markos University

Aytenew Atnaf

Debre Markos University

Abebe Abate

Debre Markos University

Melkamu Tilahun

Debre Markos University

Bekalu Kassie

Debre Markos University

Yibeltal Aschale

Debre Markos University

\section{Research}

Keywords: Parasitosis, HIV/AIDS, Determinants, Meta-analysis, Ethiopia

Posted Date: December 3rd, 2020

DOl: https://doi.org/10.21203/rs.3.rs-118269/v1 
License: (c) (i) This work is licensed under a Creative Commons Attribution 4.0 International License. Read Full License 


\section{Abstract}

Background: Intestinal parasites are a group of opportunistic gastrointestinal diseases commonly encountered among people living with human immunodeficiency virus (HIV). Intestinal parasites increased the risk of morbidity and mortality among these vulnerable populations. Therefore, to design appropriate prevention strategies, up-to-date information concerning prevalence of intestinal parasite is crucial. However, studies assessing the prevalence and associated factors of intestinal parasite in Ethiopia are inconsistent and widely varied. Therefore, this systematic review and meta-analysis is designed to assess the pooled prevalence and determine risk factors.

Methods: International databases; PubMed, Web of Science,Cochrane Library, Scopus, PsyclNFO, African Journals Online, and Google Scholar were systematically searched. A funnel plot and Egger's regression test were used to determine publication bias. The $P$ statistic was used to check heterogeneity between the studies. DerSimonian and Laird random-effects model was applied to estimate the pooled effect size. Subgroup and meta-regression analyses were conducted. Sensitivity analysis was done to see the effect of a single study on the overall estimation. STATA version 14 statistical software was used for metaanalysis.

Results: A total of 27 studies with 8,946 individuals were used to estimate the pooled prevalence of intestinal parasitosis among people living with HIV.The estimated pooled prevalence of intestinal parasitosis was $40.24 \%$ (95\% Cl: $33.8-46.6)$. Subgroup analysis of this study revealed that the highest prevalence was observed in Tigray region $45.7 \%$ (95\% Cl: 7.9-83.5), followed by Oromia region $42.2 \%$ (95\% Cl: 28.8-55.6). Availability of latrine (OR: $26.6,95 \% \mathrm{Cl}: 2.8-15.8)$, presence of animal (OR: $2.7,95 \%$ $\mathrm{Cl}: 1.2-5.8)$ and source of drinking water (OR: $3.2,95 \% \mathrm{Cl}: 1.3-7.5)$ were significantly associated with intestinal parasitosis.

Conclusion: The prevalence of intestinal parasite was high in Ethiopia. There should be a need to work for improving the hygienic standard on quality of drinking water and regular utilization of latrine among people living with HIV/AIDS.

\section{Background}

Human immunodeficiency virus (HIV) is one of the greatest challenges facing mankind. An estimated 33 million adults and children are living with the virus globally. Sub-Saharan Africa was the most affected region[1]. People with advanced stage of HIV infection are vulnerable to secondary microbial and parasitic diseases that are generally termed as opportunistic infections. This is due to the fact that they take the advantage of the opportunity offered by a weakened immune system[1,2]. About $80 \%$ of deaths of AIDS patients are related to opportunistic infections rather than the virus itself, and of these, more than $47 \%$ happen due to opportunistic intestinal parasitic infections which usually affect gastrointestinal system[3] . 
Opportunistic infection typically began to manifest when the CD4 Lymphocytes count of an infected person declines below critical level, i.e 800 cells $/ \mathrm{mm}^{3}$ of which the normal value is $1200 \mathrm{cells} / \mathrm{mm}^{3}$. When immune system is severely suppressed in this manner infection can be fatal usually resulting to death in less than two years, unless the patient receives specific therapy for HIV infection highly active anti-retroviral treatment (HAART)[2].

Intestinal parasites are the major source of morbidity and mortality in many tropical countries including Ethiopia where HIV/AIDS is endemic[4]. Protozoan infections such as: Toxoplasma gondii, Isospora belli, cryptosporidium parvum, Entameoba histolytica and Giardia lamblia and helminthic infections such as strongyloidesstercoralisare some of the most common opportunistic intestinal parasites[5, 6]. The sign and symptoms include severe chronic watery diarrhea with frequent and explosive bowel movements accompanied by loss of appetite, weight loss, abdominal cramp, nausea, fever, headache and vomiting[7]. However, intensity of infection depends on parasite factors (parasite species, length of infection, coinfection), host factors (nutritional and immunological status) and socioeconomic factors[8].

The incidence and prevalence of infection with a particular enteric parasite in HIV/AIDS patients is likely to depend upon the endemicity of that particular parasite in the community. Cryptosporidium parvum, I. belli, S.stercolarisand Toxoplasma gondihave been reported as the most frequently identified organisms in HIV infected individuals with diarrhea from Ethiopia and other parts of the world[9, 10]. Different primary studies in Ethiopia showed the magnitude of intestinal parasitosis as a great health burden in the regions. However, inconsistent and wide variation was observed among these studies. Therefore, this systematic review and meta-analysis aimed to estimate the pooled prevalence of Ips and its determinants among people living with HIV/AIDS in Ethiopia.

\section{Method}

\section{Study design and setting}

A systematic review and meta-analysis were conducted to estimate the prevalence and its determinants of intestinal parasitosis among people living with HIV in Ethiopia. It is bounded by Eritrea to the north, Djibouti, and Somalia to the east, Sudan and South Sudan to the west, and Kenya to the south[11]. Currently, 20.9\% of the population of Ethiopia is urban (23,376,340 people in 2019)[12].

\section{Search strategies}

We organized and reported this meta-analysis according to the Preferred Reporting Items for Systematic Reviews and Meta-Analysis protocols (PRISMA)[13].International electronic web-based searches of PubMed, Web of Science, Cochrane Library, Scopus, PsycINFO, African Journals Online, and Google Scholar were searched for studies to obtain primary studies. Studies were searched from 1st of May to the 1st of July, 2020.Google hand searching was also performed and the search of the reference list of already identified articles was done to retrieve additional articles. All explorations were limited to articles written in English given that such language restriction does not alter the result of the systematic reviews 
and meta-analysis [14].Gray kinds of literature observational studies were assessed through the review of reference lists. Besides, to find unpublished papers important to this systematic review and metaanalysis, some research centers, like Addis Ababa Digital Library were searched. Studies identified by our search strategy were retrieved and managed using Endnote X7 software. The search used the following keywords "prevalence", "proportion", "parasitosis", "magnitude", "and people living with HIV", "determinants", "associated factors and Ethiopia". The search terms were used individually and in combination using Boolean operators like "OR" or "AND".

\section{Eligibility criteria}

\section{Inclusion criteria}

Study area: studies conducted in Ethiopia were included

Population: Only studies involving adult people living with HIV/AIDS

Publication condition: Both published and unpublished studies were included.

Study design: All observational study designs (cross-sectional, and case-control) reporting the prevalence of intestinal parasitosis among people living with HIV/AIDS were eligible for this systematic review and meta-analysis.

\section{Exclusion criteria}

Articles, which were not wholly accessible, after at least two-email contact with the primary authors, were excluded. The exclusion of these articles is because of the difficulty to evaluate the quality of articles without getting full text. Moreover, studies which had poor quality according to the appraisal tool were also excluded.

\section{Measurement of outcome variables}

The outcomes of interest included the prevalence of intestinal parasitosis and its determinants among people living with HIV/AIDS. This study has two main outcomes. Intestinal parasitosis was defined as having recorded positive for any stage of intestinal parasites seen during microscopic examination of stool [5]. The second outcome of this study was to identify the determinants of intestinal parasitosis among People living with HIV (PLWHIV). For the second outcome, we determined the association between intestinal parasitosis and determinants in the form of the odds ratio. For major determinants, the odds ratio was calculated based on binary outcomes from the primary studies. The determinant factors included in this review were: presence of pet animals (Yes versus No), availability of latrine (Yes versus No), CD4 count of the patient, eating uncooked vegetables (Yes versus No), source of drinking water (pipe versus other), and residence (urban versus rural).

\section{Data extraction and quality assessment}


Data were extracted using a pre-piloted data extraction format prepared in a Microsoft Excel spreadsheet. The tool consisted of information regarding author/s name, year of publication, study region, study design, sample size, prevalence of intestinal parasites. The data were extracted by three independent authors. The quality of included studies was evaluated using the Joanna Briggs Institute (JBI's) critical appraisal checklist for prevalence studies [15]. Moreover, the methodological quality of studies was evaluated using a customized version of the Newcastle-Ottawa Scale (NOS) for cross-sectional studies adapted from Modesti et al. [16]. Representativeness of the sample, response rate, measurement tool used, comparability of the subject, appropriateness of the statistical test used to analyze the data are some of the key criteria in the Newcastle -Ottawa scale. Two authors independently assessed the quality of each article. Whenever necessary other reviewers were involved. Any disagreement was resolved through discussion and consensus.

\section{Data processing and analysis}

Data were extracted in Microsoft Excel format, followed by analysis using Stata Version 14 statistical software. The standard error for each original study was calculated using the binomial distribution formula. Heterogeneity among reported prevalence was assessed by computing p-values of Cochrane Qtest and $P^{2}$ statistics[17]. As the test statistic showed there is significant heterogeneity among the studies as a result a random-effects meta-analysis model was used to estimate the DerSimonian and Laird's pooled effect. In the current meta-analysis, arcsine-transformed proportions were used. The pooled prevalence was estimated by using the back-transform of the weighted mean of the transformed proportions, using arcsine variance weights for the fixed-effects model and DerSimonian-Laird weights for the random-effects model [18]. Egger's and Begg's tests at $5 \%$ significant level were significant for publication bias[19].Point estimation of intestinal parasitosis, as well as $95 \%$ confidence intervals, was reported in the forest plot format. The result of the forest plot, the size of the respective box showed the weight of each study, whereas each crossed line indicates to $95 \%$ confidence interval. For the second outcome, the odds ratio was utilized to ascertain the association between determinant factors and intestinal parasitosis in the included articles.

\section{Result}

This systematic review and meta-analysis have been reported following the PRISMA statement [20]. Initially, 579 articles related to intestinal parasitosis were accessed. Of these, 286 duplications and 257 unrelated articles were excluded. Second, from the rest 36 impending articles, 27 met eligibility for the review and included in the analysis. Nine full-text articles were excluded due to unmet outcomes of interest or study area (Fig. 1).

\section{Characteristics of included studies}

This systematic review and meta-analysis were conducted with a total sample of 8,946 people living with HIV/AIDS. The main features of the incorporated articles are described in Table 1. All of the included studies were cross-sectional in their design. Eight (29.6\%) of the studies included in this review were from 
the Oromia region[21-27], seven (25.9\%) were from the Amhara regional state[6, 9, 28-32], seven (25.9\%) were from Southern Nations Nationalities and People's (SNNPs) regional state[33-39], Two(7.4\%) studies were from Tigray regional state [26, 40] and the remaining three (11.1\%) were from Addis Ababa [41], Harar [42] and whole Ethiopia[43]. Reported burden of intestinal parasitosis ranged from $13.9 \%$ in Oromia[27]to 80.3\% in Amhara regional state[9]. The reported sample size ranged from 150 [24]to 1034[43].

\section{Quality assessment of individual studies}

Twenty-seven studies were assessed using the Joanna Briggs Institute Meta-Analysis of Statistical Assessment and Review Instrument (JBI-MAStARI) checklist for cross-sectional studies [6, 9, 21-44] [supplementary file_1]. None of the studies were excluded based on the quality assessment criteria (Table 1). 
Table 1

the characteristics of included studies for a meta-analysis of intestinal parasitosis among people living with HIV/AIDS in Ethiopia

\begin{tabular}{|c|c|c|c|c|c|c|}
\hline Authors name/Year & Region & $\begin{array}{l}\text { publication } \\
\text { year }\end{array}$ & $\begin{array}{l}\text { Study } \\
\text { Design }\end{array}$ & $\begin{array}{l}\text { Sample } \\
\text { size }\end{array}$ & $\begin{array}{l}\text { Prevalence with } \\
95 \% \mathrm{Cl}\end{array}$ & Quality \\
\hline $\begin{array}{l}\text { Alemu et al., } \\
\text { 2011[9] }\end{array}$ & Amhara & 2011 & $\begin{array}{l}\text { cross- } \\
\text { sectional }\end{array}$ & 248 & $\begin{array}{l}80.3(75.3- \\
85.3)\end{array}$ & 9 \\
\hline $\begin{array}{l}\text { Fekadu et al., } \\
\text { 2013[33] }\end{array}$ & SNNRs & 2013 & $\begin{array}{l}\text { cross- } \\
\text { sectional }\end{array}$ & 343 & $\begin{array}{l}47.8(42.5- \\
53.1)\end{array}$ & 10 \\
\hline $\begin{array}{l}\text { Zeynudin et al., } \\
\text { 2013[21] }\end{array}$ & Oromia & 2013 & $\begin{array}{l}\text { cross- } \\
\text { sectional }\end{array}$ & 91 & $\begin{array}{l}39.56(29.5- \\
49.6)\end{array}$ & 8 \\
\hline $\begin{array}{l}\text { Assefa et al., } \\
2009[34]\end{array}$ & SNNRs & 2009 & $\begin{array}{l}\text { cross- } \\
\text { sectional }\end{array}$ & 378 & $55(50.0-60.0)$ & 10 \\
\hline $\begin{array}{l}\text { Girma et al., } \\
2014[35]\end{array}$ & SNNRs & 2014 & $\begin{array}{l}\text { cross- } \\
\text { sectional }\end{array}$ & 268 & $\begin{array}{l}34.3(28.6- \\
40.0)\end{array}$ & 9 \\
\hline $\begin{array}{l}\text { Missaye et al., } \\
\text { 2013[28] }\end{array}$ & Amhara & 2013 & $\begin{array}{l}\text { cross- } \\
\text { sectional }\end{array}$ & 136 & $\begin{array}{l}17.6(11.2- \\
24.0)\end{array}$ & 9 \\
\hline $\begin{array}{l}\text { Gebrecherkos et al., } \\
2019 \text { [29] }\end{array}$ & Amhara & 2019 & $\begin{array}{l}\text { cross- } \\
\text { sectional }\end{array}$ & 150 & $\begin{array}{l}45.3(37.3- \\
53.3)\end{array}$ & 9 \\
\hline $\begin{array}{l}\text { Awole et al., } \\
2003[22]\end{array}$ & Oromia & 2003 & $\begin{array}{l}\text { cross- } \\
\text { sectional }\end{array}$ & 372 & $51.1(46.0-56.2)$ & 10 \\
\hline $\begin{array}{l}\text { Gebrewahid et al., } \\
\text { 2019[40] }\end{array}$ & Tigray & 2019 & $\begin{array}{l}\text { cross- } \\
\text { sectional }\end{array}$ & 242 & $\begin{array}{l}26.4(20.8- \\
32.0)\end{array}$ & 9 \\
\hline $\begin{array}{l}\text { Shimelis et al., } \\
\text { 2016[36] }\end{array}$ & SNNRs & 2016 & $\begin{array}{l}\text { cross- } \\
\text { sectional }\end{array}$ & 491 & $\begin{array}{l}35.8(31.6- \\
40.0)\end{array}$ & 10 \\
\hline $\begin{array}{l}\text { Gedle et al., } \\
\text { 2017[23] }\end{array}$ & Oromia & 2017 & $\begin{array}{l}\text { cross- } \\
\text { sectional }\end{array}$ & 323 & $\begin{array}{l}35.9(30.7- \\
41.1)\end{array}$ & 10 \\
\hline $\begin{array}{l}\text { Adamu et al., } \\
2013[44]\end{array}$ & Oromia & 2013 & $\begin{array}{l}\text { cross- } \\
\text { sectional }\end{array}$ & 378 & $\begin{array}{l}63.5(58.6- \\
68.4)\end{array}$ & 10 \\
\hline $\begin{array}{l}\text { Eshetu et al., } \\
\text { 2017[30] }\end{array}$ & Amhara & 2017 & $\begin{array}{l}\text { cross- } \\
\text { sectional }\end{array}$ & 223 & $\begin{array}{l}29.1(23.1- \\
35.1)\end{array}$ & 9 \\
\hline $\begin{array}{l}\text { Alemu et al., } \\
\text { 2018[37] }\end{array}$ & SNNRs & 2018 & $\begin{array}{l}\text { cross- } \\
\text { sectional }\end{array}$ & 220 & $\begin{array}{l}28.81(22.8- \\
34.8)\end{array}$ & 9 \\
\hline $\begin{array}{l}\text { Gebretsadik et al., } \\
2018[6]\end{array}$ & Amhara & 2018 & $\begin{array}{l}\text { cross- } \\
\text { sectional }\end{array}$ & 223 & 13.9(9.4-18.4) & 9 \\
\hline $\begin{array}{l}\text { Getaneh et al., } \\
2010[38]\end{array}$ & SNNRs & 2010 & $\begin{array}{l}\text { cross- } \\
\text { sectional }\end{array}$ & 384 & $25(20.7-29.3)$ & 10 \\
\hline $\begin{array}{l}\text { Gerzmu et al., } \\
2015[39]\end{array}$ & SNNRs & 2015 & $\begin{array}{l}\text { cross- } \\
\text { sectional }\end{array}$ & 209 & $\begin{array}{l}45.4(38.6- \\
52.2)\end{array}$ & 9 \\
\hline
\end{tabular}




\begin{tabular}{|lllllll|}
\hline Authors name/Year & Region & $\begin{array}{l}\text { publication } \\
\text { year }\end{array}$ & $\begin{array}{l}\text { Study } \\
\text { Design }\end{array}$ & $\begin{array}{l}\text { Sample } \\
\text { size }\end{array}$ & $\begin{array}{l}\text { Prevalence with } \\
95 \% \text { Cl }\end{array}$ & Quality \\
\hline $\begin{array}{l}\text { Kindie and Bekele, } \\
\text { 2016[24] }\end{array}$ & Oromia & 2016 & $\begin{array}{l}\text { cross- } \\
\text { sectional }\end{array}$ & 150 & $45(37.0-53.0)$ & 8 \\
\hline $\begin{array}{l}\text { Kiros et al., } \\
\text { 2015[31] }\end{array}$ & Amhara & 2015 & $\begin{array}{l}\text { cross- } \\
\text { sectional }\end{array}$ & 399 & $\begin{array}{l}30.6(26.1- \\
35.1)\end{array}$ & 9 \\
\hline $\begin{array}{l}\text { Mariam et al., } \\
\text { 2008[25] }\end{array}$ & Oromia & 2008 & $\begin{array}{l}\text { cross- } \\
\text { sectional }\end{array}$ & 160 & $\begin{array}{l}62.5(55.0- \\
70.0)\end{array}$ & 8 \\
\hline $\begin{array}{l}\text { Mahmud et al., } \\
\text { 2014[26] }\end{array}$ & Tigray & 2014 & $\begin{array}{l}\text { cross- } \\
\text { sectional }\end{array}$ & 384 & $65(60.2-69.8)$ & 10 \\
\hline $\begin{array}{l}\text { Mahmud et al., } \\
\text { 2014 }\end{array}$ & Oromia & 2014 & $\begin{array}{l}\text { cross- } \\
\text { sectional }\end{array}$ & 520 & $\begin{array}{l}26.9(23.1- \\
30.7)\end{array}$ & 10 \\
\hline $\begin{array}{l}\text { Taye et al., 2014[41] } \\
\text { Other }\end{array}$ & 2014 & $\begin{array}{l}\text { cross- } \\
\text { sectional }\end{array}$ & 546 & $\begin{array}{l}33.9(29.9- \\
37.9)\end{array}$ & 10 \\
\hline $\begin{array}{l}\text { Teklemariam et al., } \\
\text { 2013[42] }\end{array}$ & Other & 2013 & $\begin{array}{l}\text { cross- } \\
\text { sectional }\end{array}$ & 371 & $\begin{array}{l}33.7(28.9- \\
38.5)\end{array}$ & 9 \\
\hline $\begin{array}{l}\text { Dufera et al., } \\
\text { 2008[27] }\end{array}$ & Oromia & 2008 & $\begin{array}{l}\text { cross- } \\
\text { sectional }\end{array}$ & 296 & $13.9(10.0-17.8)$ & 9 \\
\hline $\begin{array}{l}\text { Adamu et al., } \\
\text { 2010[43] }\end{array}$ & Other & 2010 & $\begin{array}{l}\text { cross- } \\
\text { sectional }\end{array}$ & 1034 & $52(49.0-55.0)$ & 10 \\
\hline $\begin{array}{l}\text { Yabsira et } \\
\text { al.2019[32] }\end{array}$ & Amhara & 2019 & $\begin{array}{l}\text { cross- } \\
\text { sectional }\end{array}$ & 407 & $\begin{array}{l}49.1(44.2- \\
54.0)\end{array}$ & 9 \\
\hline
\end{tabular}

\section{The burden of intestinal parasitosis among people living with HIV/AIDS in Ethiopia}

Generally, the pooled prevalence of intestinal parasitosis among people living with HIV/AIDS in Ethiopia was $40.24 \%$ (95\% Cl: 33.8-46.6) (Fig. 2). The lowest (13.9\%) and highest (80.3\%) prevalence of intestinal parasitosis was reported in Oromia[27]and Amhara region respectively[9].The result of $\mathrm{I}^{2}$ test static for heterogeneity indicated that the studies varied significantly $\left(I^{2}=97.7 \%, p<0.001\right)$ and because hypothetically we supposed large differences in the study settings and socio-economic backgrounds, we fitted a DerSimonian and Laird random-effect model to estimate the pooled prevalence of intestinal parasitosis $[45,46]$. The study with the largest weight was $3.78 \%[43]$ and a slightly smaller weight of $3.48 \%$ was given to a study conducted in Oromia regional state[21]. In the sub-group analysis by region, the highest pooled prevalence of intestinal parasitosis was found in the Tigray regional state $45.7 \%$ (95\% Cl: 7.9, 83.5), followed by Oromia regional state $42.2 \%$ (95\% Cl: $28.8,55.6)$, and in SNNRs $38.8 \%$ (95\% Cl: $30.5,47.2)$ and the lowest pooled prevalence was in Amhara regional state $37.99 \%$ (95\% Cl: 20.1, 55.9) (Fig. 3). The sub-group analysis indicated the presence of heterogeneity across the studies. To identify 
the source of heterogeneity, we conducted meta-regression and sensitivity analysis. The meta-regression analysis was performed using publication years, sample size, and the region as study covariates.

However, the results showed that the sample size was a statically significant source of heterogeneity. We also performed sensitivity analyses to assess the effect of each study on the overall effect size. No single study significantly affected the overall pooled estimate.

\section{Heterogeneity and publication bias}

Given that the result of this meta-analysis revealed statistically significant heterogeneity among studies $\left(I^{2}=97.7 \%\right)$, we executed a subgroup analysis by region to adjust and decrease heterogeneity (Fig. 3 ). Additionally, to distinguish the potential source of heterogeneity, we performed meta-regression analysis using sample size, study setting/ region, and publication year as covariates (Table 2). However, none of them significantly affected heterogeneity between studies. We assessed publication bias using both Begg's and Egger's test and these tests showed that there was no statistical evidence of publication bias with p-value greater than 0.05 and the funnel plot was symmetry(Fig. 4). Besides, in sensitivity analysis none of the studies had a significant effect on the pooled prevalence estimates and measures of heterogeneity within primary studies. Therefore, sensitivity analyses using the random effects model revealed that no single study influenced the overall prevalence of intestinal parasites among people living with HIV/AIDS (Fig. 5).

Table 2

Meta-regression for the included studies to identify the source of heterogeneity for intestinal parasitosis

\begin{tabular}{|llll|}
\hline Variables & Characteristics & Coefficient & P-value \\
\hline Publication Year & Publication year & -1.20 & 0.149 \\
\hline Sample size & Sample size & 0.01 & 0.55 \\
\hline Region & Amhara & -3.04 & 0.68 \\
\cline { 2 - 3 } & Oromia & 2.75 & 0.7 \\
\hline SNNRs & -1.87 & 0.8 \\
\hline & Others & -0.38 & 0.9 \\
\hline & Tigray & 5.9 & 0.6 \\
\hline
\end{tabular}

\section{Determinants of intestinal parasitic infection in Ethiopia}

The association of drinking water source and intestinal parasitosis:- In this meta-analysis, the association of intestinal parasitosis with source of drinking water had been seen using eight studies conducted in Ethiopia[6, 23, 24, 28, 29, 36, 37, 41].The meta-analysis of these studies revealed that intestinal parasitosis among people living with HIV/AIDS was significantly associated with the drinking water from unprotected sources (OR: $3.15,95 \% \mathrm{Cl}$ : 1.32-7.5). Specifically, the likelihood of getting intestinal parasitic 
infection was around three times higher among HIV/ infected people who drink unprotected water source compared to HIV infected people drinking from pipe water. The test result of this meta-analysis revealed heterogeneity among ten studies $\left(l^{2}=74.9 .0 \%, p<0.001\right)$. So, the random effect meta-analysis model was used to see the association of drinking water source and intestinal parasitosis in Ethiopia (Fig. 6).

The association between availability of latrine and intestinal parasitic infection: Besides, the association of availability and intestinal parasitosis was examined using eight studies conducted in Ethiopia[6, 23, $24,29,30,36,37,41]$. In this meta- analysis availability of latrine was found to be significantly associated with occurrence of intestinal parasitosis (OR: 6.65, 95\% Cl: 2.79-15.84). Particularly, people living with HIV/AIDS who have no latrine in their compound were around seven times more likely to be infected with intestinal parasites compared to counter parts who had latrine. The test statistics of these thirteen studies showed significant heterogeneity among studies $\left(I^{2}=78.4 \%, P<0.001\right)$. As a result, a random effect meta-analysis method was used (Fig. 7).

The association between intestinal parasitosis and presence of animal in home: Four studies were included to examine the association between the intestinal parasitosis among people living with HIV/AIDS and presence of animals in home[23, 28, 36, 37]. The meta-analysis of these studies revealed that the presence of animals in home was found to be significantly associated with intestinal parasitosis (OR: $2.69,95 \% \mathrm{Cl}: 1.24-5.84$ ). In particular, HIV infected people who had animals in their home were around three times more likely to be infected with intestinal parasites compared to those who had no animals in their home (Fig. 8).

\section{Discussion}

This systematic review and meta-analysis were intended to see the pooled prevalence and determinants of intestinal parasitic infection among people living with HIV/AIDS in Ethiopia. Based on the finding of this study the pooled prevalence of intestinal parasitosis was $40.24 \%$ ). Subgroup analysis of this study revealed that the highest prevalence of intestinal parasite was observed in Tigray regional state $45.7 \%$, followed by Oromia regional state $42.2 \%$. Availability of latrine, presence of animal in home and source of drinking water other than pipe were significantly associated with intestinal parasitosis.

The finding of this study was found to be comparable with studies conducted in SaudiArabia $39.7 \%$, and Ghana (35\%)[47]. It is higher compared to studies conducted in Nepal 32\%[48] Nigeria 28.3\%, 22.7\%, 5.3\% [49-51], India 35\% [52], Senegal 10.6\%[53], Democratic Republic of Congo(15.4\%)[54], and Cameroon (14.64\%) [1]. These variations in findings among the studies might be explained by differences in geographical locations, socioeconomic conditions and cultural practices of the population. The methods exercised for stool examination and the time of the study might also have contributed for the differences. The higher proportion of intestinal parasites in this study might also be due to the difference in geographical and environmental conditions. In addition, the lower access to water supply and sanitation in Ethiopia may contribute to the high magnitude of intestinal parasites. High prevalence of IP infections among the study participants may call for better follow-up through laboratory tests and more 
comprehensive actions by the patients themselves in adopting prevention measures against intestinal parasites. But the current finding is significantly lower than study conducted in Brazil 63.9\% [55], Cameroon 82.6\%[56], India 62.7\%[57] Thailand 50\%[58], Democratic republic of Congo 49.7\% [54], Kenya (50.9\%)[59]. This lower prevalence of parasite in this study could be due to the variation in sample size, and the environmental difference. It might be also due to better-quality care delivered to people living with HIV/AIDS and faithfulness to ART. The regular advice conveyed by healthcare providers for HIV positive patients during their frequent visit to ART clinic could contribute for lowering prevalence of intestinal parasitic infection.

Based on this Mata-analysis and systematic review, absence of toilet was found to be significantly associated with the occurrence of intestinal parasitosis. Particularly, HIV positive individuals who had no latrine in their compound were found to be 6.65 times more likely to be infected with intestinal parasites compared to the counter parts that have toilet in their compound. The finding of this meta-analysis and systematic review was supported by studies conducted in Nigeria and Malaysia [49, 60, 61]. They reported absence of latrine was an independent predictor of intestinal parasitic infection. This is due to the fact that failure to access latrine causes in unguarded defecation and environmental contamination. Thus, it facilitates the likelihood transmission of intestinal parasitic infections (IPIs). In addition, the source of drinking water was found to be significantly associated with high prevalence of intestinal parasitic infection. Specifically, People living with HIV/AIDS who do not use pipe water 3.15 times more likely to be infected by intestinal parasites compared to people living with HIV/AIDS who use pipe water. This finding was supported by studies conducted in Malaysia[60]and Nigeria[49] which stated source of drinking water was a significant determinant of intestinal parasitic infection. It is fact that, river/unprotected water is highly contaminated with animals and human excreta since people is usually bathing and washing their clothes under river. These habits have been practiced in developing countries particularly in Ethiopia due to scarcity or inadequate distribution of safe/clean water. So, using untreated/unsafe water contributes to be infected with one or more intestinal parasitic infections[62, 63]. The most prevalent waterborne intestinal parasites producing diarrhea were Cryptosporidium parvum, G.lamblia, and E. histolytica. These parasitic infections have been commonly reported in immunecompromised patients, particularly in HIV/AIDS patients[62].

Besides, a significant association was found between presence of animal in home and intestinal parasitic infection. Specifically, people living with HIV/AIDS who had pet animal living in their home were 2.69 times more likely to be infected with intestinal parasites compared to those who did not have animals in their home. This finding was in line with studies in India $[57,64]$ which revealed the presence of animals was a significant risk factor of intestinal parasitic infection. The association might be due to living of human with domestic animals which increases a tendency to contact with pet or domestic animal excretion and consuming their products. So, those patients will be more vulnerable to be infected with one or more intestinal parasites[65, 66].

\section{Limitations of the study}


One of the limitations of this systematic review and meta-analysis was only studies written by English language were incorporated for the pooled estimate. Furthermore, the results of this study may not represent the real figure of the country, since studies had not been found in Afar, Somalia and Benishangul-Gumuz.

\section{Conclusion And Recommendations}

A high prevalence of intestinal parasitic infections was observed in people living with HIV. There is a need for awareness creation towards better access for safe water, separation of animals from home and to have latrine in their vicinity for the prevention of intestinal parasites.

\section{Abbreviations}

AIDS Acquired Immune Deficiency Syndrome

ART Anti-Retroviral Therapy

CD4 Cluster for Differentiation

Cl Confidence Interval

IPs Intestinal Parasite

HIV Human Immunodeficiency Virus

OR Odds Ratio

OIPI Opportunistic Intestinal parasitic infection

WHO World Health Organization

\section{Declarations}

\section{Ethics approval and consent to participate}

Not applicable

Consent for publication

Not applicable

\section{Availability of data and material}

The datasets analyzed during the current study are available from the corresponding author Upon reasonable request. 
Competing interests

We have confirmed that we have no competing interests.

Funding

No funding was obtained for this study.

Authors' contributions

All authors made substantial contributions to conception and design, acquisition of data, or analysis and interpretation of data; took part in drafting the article or revising it critically for important intellectual content; gave final approval of the version to be published; and agree to be accountable for all aspects of the work.

Acknowledgments

Not applicable

\section{References}

1. Nkenfou CN, Nana CT, Payne VK: Intestinal parasitic infections in HIV infected and non-infected patients in a low HIV prevalence region, West-Cameroon. PloS one 2013, 8(2):e57914.

2. Rao KA, Mir B, Sirwar A, Indupalli AS, Shahid M: A study on opportunistic parasitic \& fungal infections in HIV patients in rural Hospital at sangareddy, Andhra Pradesh. International Journal of Biological \& Medical Research 2012, 3(4):2415-2417.

3. Akinbo F, Okaka C, Machado R, Omoregie R, Onunu A: Cryptosporidiosis among HIV-infected patients with diarrhea in Edo State, Midwestern Nigeria. Malaysian J Microbiol 2010, 6(1):99-101.

4. Kumie A, Ali A: An overview of environmental health status in Ethiopia with particular emphasis to its organization, drinking water and sanitation: a literature survey. Ethiopian Journal of Health Development 2005, 19(2):89.

5. Dessie A, Gebrehiwot TG, Kiros B, Wami SD, Chercos DH: Intestinal parasitic infections and determinant factors among school-age children in Ethiopia: a cross-sectional study. $B M C$ research notes 2019, 12(1):777.

6. Gebretsadik D, Haileslasie H, Feleke DG: Intestinal parasitosis among HIV/AIDS patients who are on anti-retroviral therapy in Kombolcha, North Central, Ethiopia: a cross-sectional study. BMC research notes 2018, 11(1):613.

7. Mathers CD, Loncar D: Projections of global mortality and burden of disease from 2002 to 2030. PLoS medicine 2006, 3(11):e442.

8. Srirangaraj S, Venkatesha D: Opportunistic infections in relation to antiretroviral status among AIDS patients from south India. Indian Journal of medical microbiology 2011, 29(4):395. 
9. Alemu A, Shiferaw Y, Getnet G, Yalew A, Addis Z: Opportunistic and other intestinal parasites among HIV/AIDS patients attending Gambi higher clinic in Bahir Dar city, North West Ethiopia. Asian Pacific Journal of Tropical Medicine 2011, 4(8):661-665.

10. Manandhar S, Sapkota D, Ghimire P: Enteric Parasitosis in Patients with Human Immunodeficiency Virus (HIV) Infection and Acquired Immunodeficiency Syndrome (AIDS) in Nepal. Journal of Nepal Health Research Council 2004.

11. ETHIOPIA Location \& Size: Geography - OSU http://u.osu.edu/ockerman.2/files/2014/03/Ethiopia117cwe5.pdf.

12. Population of Ethiopia (2019 and historical) https://www.worldometers.info/worldpopulation/ethiopia-population/.

13. Liberati A, Altman DG, Tetzlaff J, Mulrow C, Gøtzsche PC, loannidis JP, Clarke M, Devereaux PJ, Kleijnen J, Moher D: The PRISMA statement for reporting systematic reviews and meta-analyses of studies that evaluate health care interventions: explanation and elaboration. PLoS medicine 2009, 6(7):e1000100.

14. Moher $D$, Pham B, Lawson $M$, Klassen $T$ : The inclusion of reports of randomised trials published in languages other than English in systematic reviews. Health Technol Assess 2003, 7(41):1-90.

15. Munn Z, Moola S, Riitano D, Lisy K: The development of a critical appraisal tool for use in systematic reviews addressing questions of prevalence. International journal of health policy and management 2014, 3(3):123.

16. Modesti PA, Reboldi G, Cappuccio FP, Agyemang C, Remuzzi G, Rapi S, Perruolo E, Parati G: Panethnic differences in blood pressure in Europe: a systematic review and meta-analysis. PloS one 2016, 11(1):e0147601.

17. Rücker G, Schwarzer G, Carpenter JR, Schumacher M: Undue reliance on I 2 in assessing heterogeneity may mislead. BMC medical research methodology 2008, 8(1):79.

18. Nyaga VN, Arbyn M, Aerts M: Metaprop: a Stata command to perform meta-analysis of binomial data. Archives of Public Health 2014, 72(1):39.

19. Borenstein M, Hedges LV, Higgins JP, Rothstein HR: A basic introduction to fixed-effect and randomeffects models for meta-analysis. Research synthesis methods 2010, 1(2):97-111.

20. Moher D, Shamseer L, Clarke M, Ghersi D, Liberati A, Petticrew M, Shekelle P, Stewart LA: Preferred reporting items for systematic review and meta-analysis protocols (PRISMA-P) 2015 statement. Systematic reviews 2015, 4(1):1.

21. Zeynudin A, Hemalatha K, Kannan S: Prevalence of opportunistic intestinal parasitic infection among HIV infected patients who are taking antiretroviral treatment at Jimma Health Center, Jimma, Ethiopia. Eur Rev Med Pharmacol Sci 2013, 17(4):513-516.

22. Awole M, Gebre-Selassie S, Kassa T, Kibru G: Prevalence of intestinal parasites in HIV-infected adult patients in southwestern Ethiopia. Ethiopian Journal of Health Development 2003, 17(1):71-78.

23. Gedle D, Kumera G, Eshete T, Ketema K, Adugna H, Feyera F: Intestinal parasitic infections and its association with undernutrition and CD4 T cell levels among HIV/AIDS patients on HAART in 
Butajira, Ethiopia. Journal of Health, Population and Nutrition 2017, 36(1):15.

24. Kindie Y, Bekele S: Prevalence and risk factors for intestinal parasite infections in HIV/AIDS patients with anti-retroviral treatment in South West Ethiopia. J Trop Dis 2016, 4:210.

25. Mariam ZT, Abebe G, Mulu A: Opportunistic and other intestinal parasitic infections in AIDS patients, HIV seropositive healthy carriers and HIV seronegative individuals in southwest Ethiopia. East African journal of public health 2008, 5(3):169-173.

26. Mahmud MA, Bezabih AM, Gebru RB: Risk factors for intestinal parasitosis among antiretroviraltreated HIV/AIDS patients in Ethiopia. International journal of STD \& AIDS 2014, 25(11):778-784.

27. Dufera M, Petros B, Endeshaw T, Mohammed H, Kassu A: Opportunistic intestinal protozoan parasites among HIV positive patients on antiretroviral therapy at Nekemte hospital, West Ethiopia. Ethiop J Health Biomed Sci 2008, 1(Suppl 1):11-17.

28. Missaye A, Dagnew M, Alemu A, Alemu A: Prevalence of intestinal parasites and associated risk factors among HIV/AIDS patients with pre-ART and on-ART attending dessie hospital ART clinic, Northeast Ethiopia. AIDS research and therapy 2013, 10(1):7.

29. Gebrecherkos T, Kebede H, Gelagay AA: Intestinal parasites among HIV/AIDS patients attending University of Gondar Hospital, northwest Ethiopia. Ethiopian Journal of Health Development 2019, 33(2).

30. Eshetu T, Sibhatu G, Megiso M, Abere A, Baynes HW, Biadgo B, Zeleke AJ: Intestinal parasitosis and their associated factors among people living with HIV at University of Gondar Hospital, NorthwestEthiopia. Ethiopian journal of health sciences 2017, 27(4):411-420.

31. Kiros $H$, Nibret $E$, Munshea $A$, Kerisew $B$, Adal M: Prevalence of intestinal protozoan infections among individuals living with HIV/AIDS at Felegehiwot Referral Hospital, Bahir Dar, Ethiopia. International journal of infectious diseases 2015, 35:80-86.

32. Gebeyew Y: Prevalence and associated factors of intestinal parasites among people living with HIV/AIDS on antiretroviral treatment in Debre Markos referral hospital, north west Ethiopia 2019. 2019.

33. Fekadu S, Taye K, Teshome W, Asnake S: Prevalence of parasitic infections in HIV-positive patients in southern Ethiopia: a cross-sectional study. The Journal of Infection in Developing Countries 2013, 7(11):868-872.

34. Assefa S, Erko B, Medhin G, Assefa Z, Shimelis T: Intestinal parasitic infections in relation to HIV/AIDS status, diarrhea and CD4 T-cell count. BMC infectious diseases 2009, 9(1):155.

35. Girma M, Teshome W, Petros B, Endeshaw T: Cryptosporidiosis and Isosporiasis among HIV-positive individuals in south Ethiopia: a cross sectional study. BMC infectious diseases 2014, 14(1):100.

36. Shimelis T, Tassachew Y, Lambiyo T: Cryptosporidium and other intestinal parasitic infections among HIV patients in southern Ethiopia: significance of improved HIV-related care. Parasites \& vectors 2016, 9(1):270.

37. Alemu G, Alelign D, Abossie A: Prevalence of opportunistic intestinal parasites and associated factors among HIV patients while receiving ART at Arba Minch Hospital in southern Ethiopia: a cross- 
sectional study. Ethiopian journal of health sciences 2018, 28(2):147-156.

38. Getaneh A, Medhin G, Shimelis T: Cryptosporidium and Strongyloides stercoralis infections among people with and without HIV infection and efficiency of diagnostic methods for Strongyloides in Yirgalem Hospital, southern Ethiopia. BMC research notes 2010, 3(1):90.

39. Gerzmu T, Fantahun E, Hailu E, Kibe H, Fesseha O, Godana W: Prevalence of intestinal parasitosis among HIV/AIDS patients attending ART clinic of Arbaminch Hospital. Afr J Sci Res 2015, 4(5):1317.

40. Gebrewahid T, Gebrekirstos G, Teweldemedhin M, Gebreyesus H, Awala A, Tadla K: Intestinal parasitosis in relation to CD4 count and anemia among ART initiated patients in St. Mary Aksum general hospital, Tigray, Ethiopia. BMC infectious diseases 2019, 19(1):350.

41. Taye B, Desta K, Ejigu S, Dori GU: The magnitude and risk factors of intestinal parasitic infection in relation to Human Immunodeficiency Virus infection and immune status, at ALERT Hospital, Addis Ababa, Ethiopia. Parasitology international 2014, 63(3):550-556.

42. Teklemariam Z, Abate D, Mitiku H, Dessie Y: Prevalence of intestinal parasitic infection among HIV positive persons who are naive and on antiretroviral treatment in Hiwot Fana Specialized University Hospital, Eastern Ethiopia. Isrn Aids 2013, 2013.

43. Adamu H: The prevalence of intestinal parasites and molecular characterization of cryptosporidium species in Ethiopia. Addis Ababa University; 2010.

44. Adamu $\mathrm{H}$, Wegayehu $\mathrm{T}$, Petros $\mathrm{B}$ : High prevalence of diarrhoegenic intestinal parasite infections among non-ART HIV patients in Fitche Hospital, Ethiopia. PloS one 2013, 8(8).

45. Kelley GA, Kelley KS: Statistical models for meta-analysis: A brief tutorial. World journal of methodology 2012, 2(4):27.

46. Jackson D, Bowden J, Baker R: How does the DerSimonian and Laird procedure for random effects meta-analysis compare with its more efficient but harder to compute counterparts? Journal of Statistical Planning and Inference 2010, 140(4):961-970.

47. Boaitey YA, Nkrumah B, Idriss A, Tay SCK: Gastrointestinal and urinary tract pathogenic infections among HIV seropositive patients at the Komfo Anokye Teaching Hospital in Ghana. BMC research notes 2012, 5(1):454.

48. Adhikari NA, Rai SK, Singh A, Dahal S, Ghimire G: Intestinal parasitic infections among HIV seropositive and high risk group subjects for HIV infection in Nepal. Nepal Medical College journal: NMCJ 2006, 8(3):166-170.

49. PA R, IE NDHC, RIA E: Prevalence of intestinal parasites seen in HIV sero-positive subjects in Port Harcourt, Nigeria. Nigerian Journal of Parasitology 2008, 29(2):115-120.

50. Abaver D, Nwobegahay J, Goon D, Iweriebor B, Anye D: Prevalence of intestinal parasitic infections among HIV/AIDS patients from two health institutions in Abuja, Nigeria. African health sciences 2011, 11:24-27.

51. Akinbo FO, Omoregie R: Intestinal parasitic infections in human-immunodeficiency-virus-infected persons on highly active antiretroviral therapy in Benin City, Nigeria. Genomic Medicine, Biomarkers, 
and Health Sciences 2011, 3(3-4):119-122.

52. Kulkarni S, Kairon R, Sane S, Padmawar P, Kale V, Thakar M, Mehendale S, Risbud A: Opportunistic parasitic infections in HIV/AIDS patients presenting with diarrhoea by the level of immunesuppression. Indian Journal of Medical Research 2009, 130(1):63.

53. Faye B, Tine R, Ndiaye J, Kintega C, Manga N, Sow P, Gaye O: Impact of intestinal parasites on intensity of HIV infection in senegal. Journal of Antivirals and Antiretrovirals 2010, 2(1):11-12.

54. Wumba R, Longo-Mbenza B, Mandina M, Wobin TO, Biligui S, Sala J, Breton J, Thellier M: Intestinal parasites infections in hospitalized AIDS patients in Kinshasa, Democratic Republic of Congo. Parasite 2010, 17(4):321-328.

55. Bachur TPR, Vale JM, Coêlho ICB, Queiroz TRBSd, Chaves CdS: Enteric parasitic infections in HIV/AIDS patients before and after the highly active antiretroviral therapy. Brazilian Journal of Infectious Diseases 2008, 12(2):115-122.

56. Nsagha DS, Njunda LA, Assob NJC, Ayima CW, Tanue EA, Kibu OD, Kwenti TE: Prevalence and predisposing factors to intestinal parasitic infections in HIV/AIDS patients in Fako Division of Cameroon. American Journal of Epidemiology 2017, 5(3):42-49.

57. Dwivedi KK, Prasad G, Saini S, Mahajan S, Lal S, Baveja UK: Enteric opportunistic parasites among HIV infected individuals: associated risk factors and immune status. Japanese journal of infectious diseases 2007, 60(2/3):76.

58. Wiwanitkit V: Intestinal parasitic infections in Thai HIV-infected patients with different immunity status. BMC gastroenterology 2001, 1(1):3.

59. Kipyegen CK, Shivairo RS, Odhiambo RO: Prevalence of intestinal parasites among HIV patients in Baringo, Kenya. Pan African Medical Journal 2012, 13(1).

60. Ngui R, Ishak S, Chuen CS, Mahmud R, Lim YA: Prevalence and risk factors of intestinal parasitism in rural and remote West Malaysia. PLoS Negl Trop Dis 2011, 5(3):e974.

61. Al-Mekhlafi M, Atiya A, Lim Y, Mahdy A, Ariffin W, Abdullah HC, Surin J: An unceasing problem: soiltransmitted helminthiases in rural Malaysian communities. Southeast Asian journal of tropical medicine and public health 2007, 38(6):998-1007.

62. Baldursson S, Karanis P: Waterborne transmission of protozoan parasites: review of worldwide outbreaks-an update 2004-2010. Water research 2011, 45(20):6603-6614.

63. Slifko TR, Smith HV, Rose JB: Emerging parasite zoonoses associated with water and food. International journal for parasitology 2000, 30(12-13):1379-1393.

64. Ram Mohan M, Nagamani K, Saxena N: Enteric parasites in HIV/AIDS patients: study of the prevalence and risk factors. Int J Biomed Res 2013, 4:2-5.

65. Alyousefi NA, Mahdy MA, Mahmud R, Lim YA: Factors associated with high prevalence of intestinal protozoan infections among patients in Sana'a City, Yemen. PloS one 2011, 6(7):e22044.

66. Glaser CA, Angulo FJ, Rooney JA: Animal-associated opportunistic infections among persons infected with the human immunodeficiency virus. Clinical Infectious Diseases 1994, 18(1):14-24. 
Figures

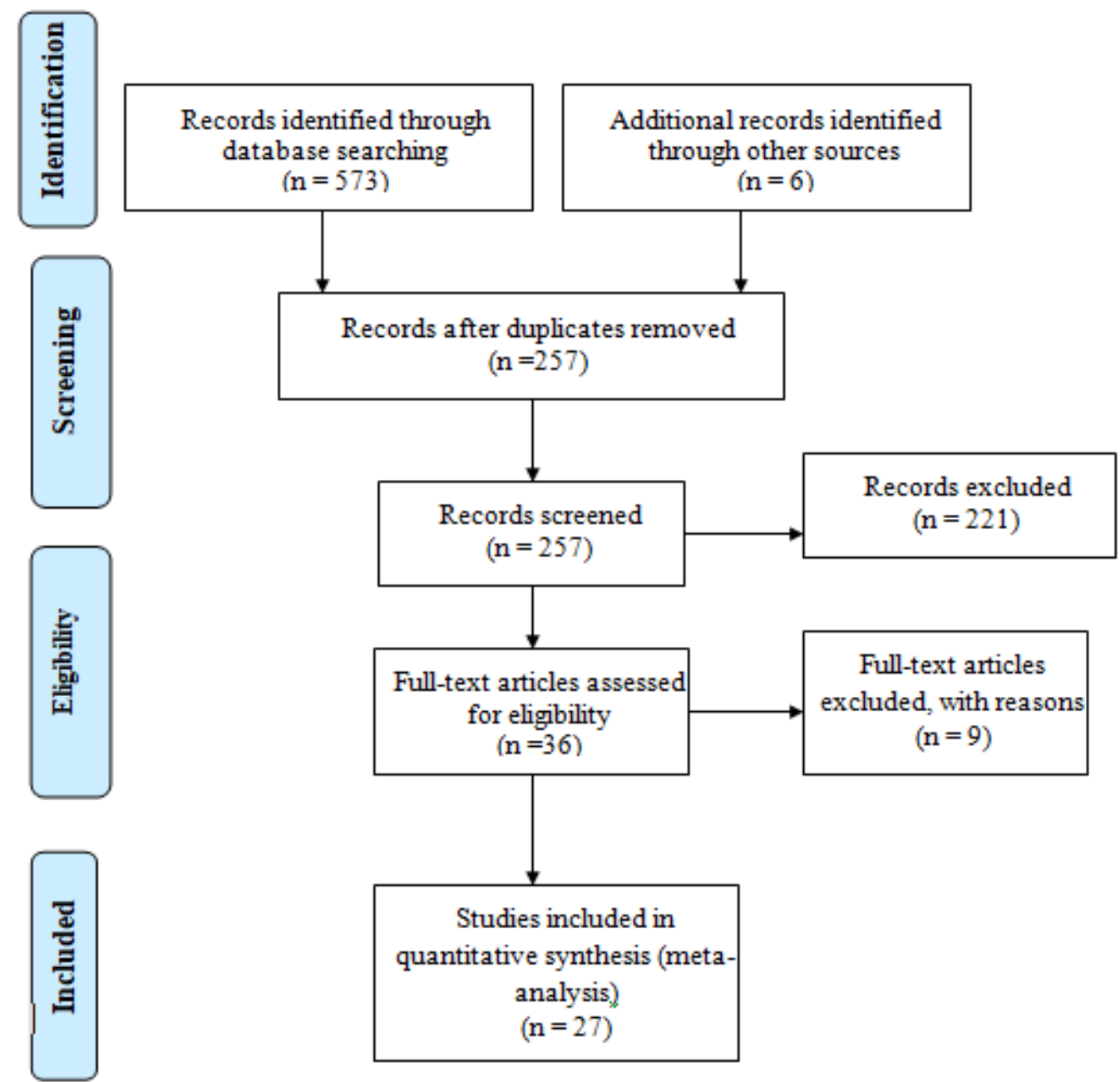

\section{Figure 1}

Flowchart diagram describing the selection of studies for a meta-analysis of intestinal parasitosis among people living with HIV/AIDS in Ethiopia. 
Alemu et al., 2011

Fekadu et al., 2013

Zeynudin et al., 2013

Assefa et al., 2009

Girma et al., 2014

Missaye et al., 2013

Gebrecherkos et al., 2019

Awole et al., 2003

Gebrewahid et al., 2019

Shimelis et al., 2016

Gedle et al., 2017

Adamu et al., 2013

Eshetu et al., 2017

Alemu et al., 2018

Gebretsadik et al., 2018

Getaneh et al., 2010

Gerzmu et al., 2015

Kindie and Bekele, 2016

Kiros et al., 2015

Mariam et al., 2008

Mahmud et al., 2014

Mahmud et al., 2014

Taye et al., 2014

Teklemariam et al., 2013

Dufera et al., 2008

Adamu et al., 2010

Yabsira et al.2019

Overall (l-squared $=97.7 \%, p \leq 0.001$ )

NOTE: Weights are from random effects analysis
$80.30(75.35,85.25)$

$47.80(42.51,53.09)$

$39.56(29.51,49.61)$

$55.00(49.98,60.02)$

$34.30(28.62,39.98)$

$17.60(11.20,24.00)$

$45.30(37.33,53.27)$

$51.10(46.02,56.18)$

$26.40(20.85,31.95)$

$35.80(31.56,40.04)$

$35.90(30.67,41.13)$

$63.50(58.65,68.35)$

$29.10(23.14,35.06)$

$28.81(22.83,34.79)$

$13.90(9.36,18.44)$

$25.00(20.67,29.33)$

$45.40(38.65,52.15)$

$45.00(37.04,52.96)$

$30.60(26.08,35.12)$

$62.50(55.00,70.00)$

$65.00(60.23,69.77)$

$26.90(23.09,30.71)$

$33.90(29.93,37.87)$

$33.70(28.89,38.51)$

$13.90(9.96,17.84)$

$52.00(48.95,55.05)$

$49.10(44.24,53.96)$

$40.24(33.86,46.63)$

\section{Figure 2}

forest plot showing the pooled estimate of intestinal parasitosis among people living with HIV/AIDS in Ethiopia 


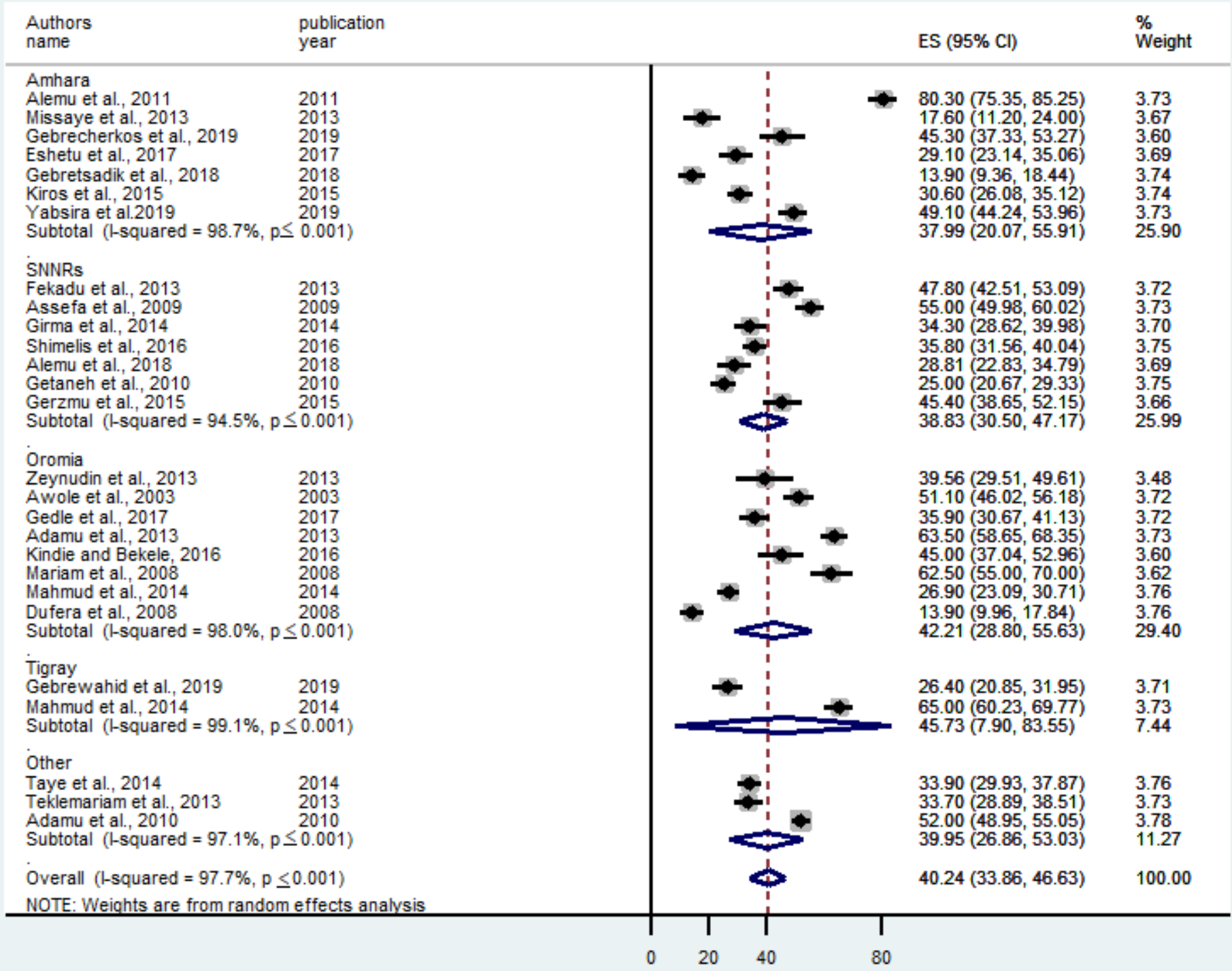

\section{Figure 3}

forest plot showing the subgroup analysis for prevalence of intestinal parasitosis in Ethiopia 


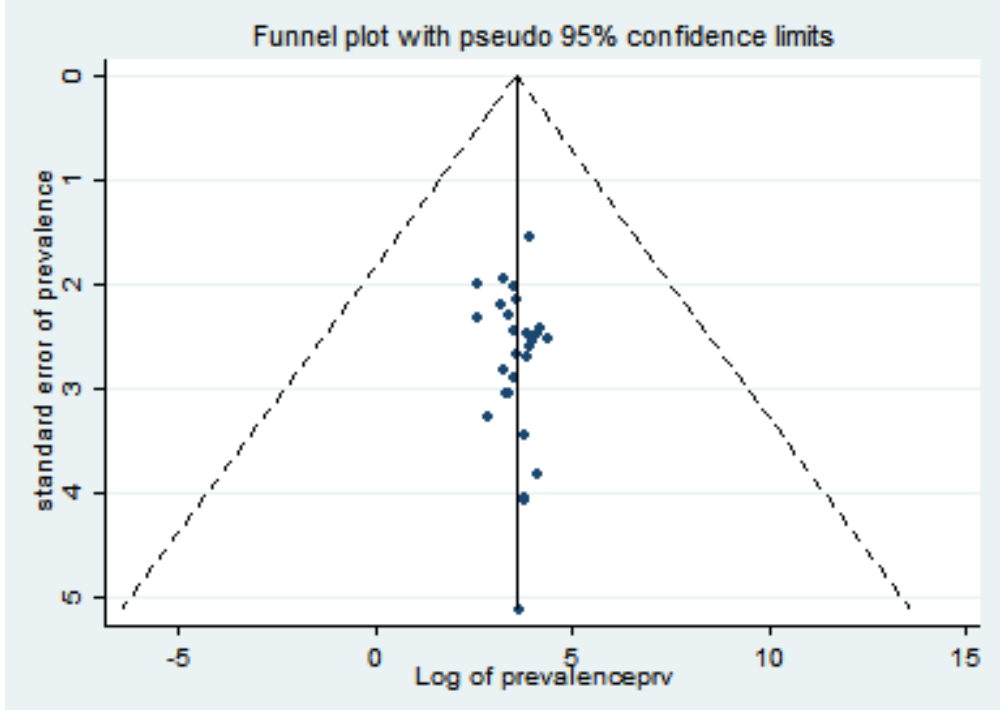

Figure 4

Funnel plot to test publication bias of the included studies.

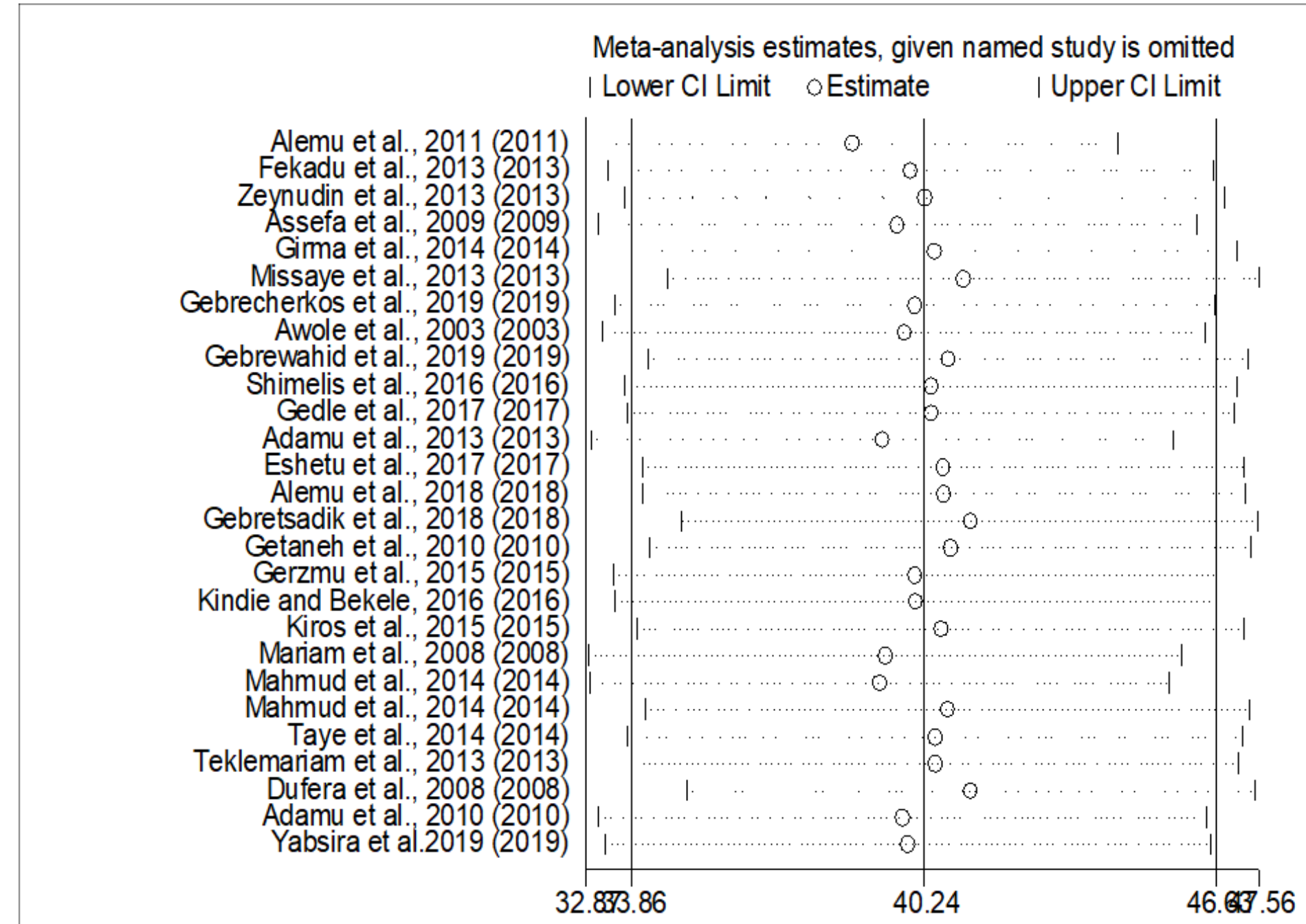


Figure 5

Result of sensitivity analysis of the included studies

$\%$

Author /Year

OR $(95 \% \mathrm{Cl})$

Weight

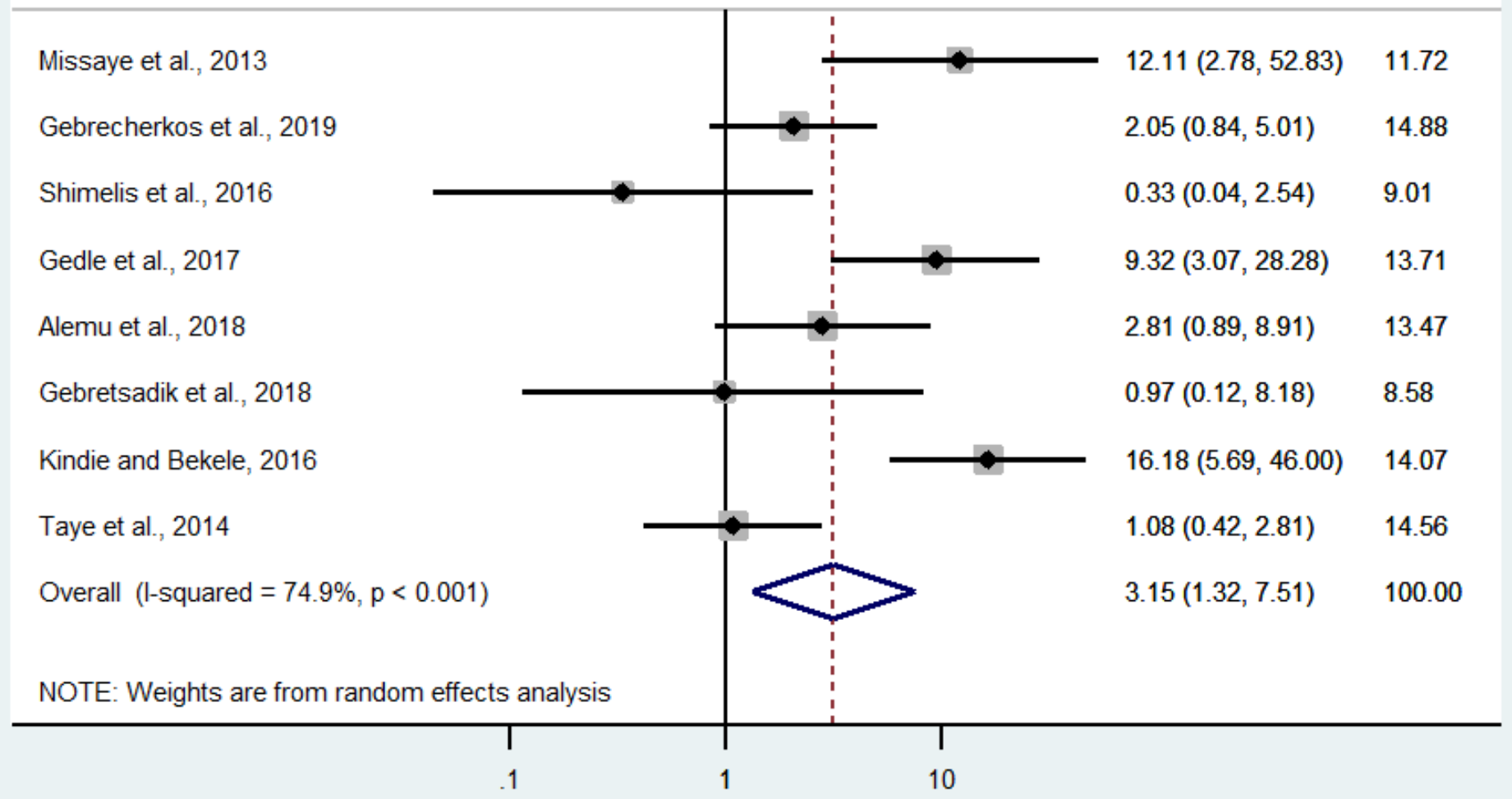

\section{Figure 6}

Forest plot showing the pooled odds ratio of the association between source of drinking water and intestinal parasitosis among people living with HIV/AIDS in Ethiopia 
Author / Year

OR $(95 \% \mathrm{Cl})$

Weight

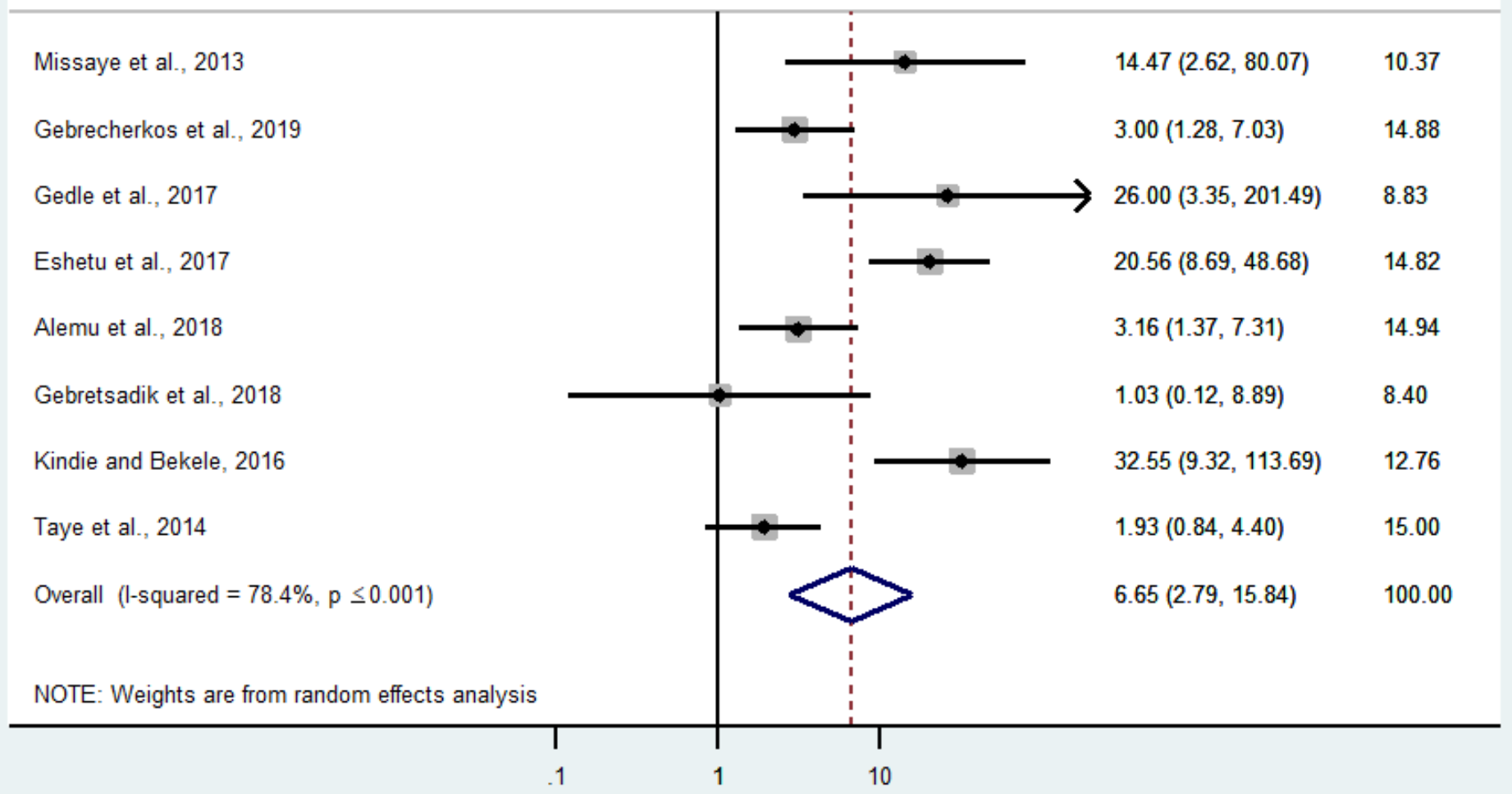

\section{Figure 7}

Forest plot showing pooled odds ratio for the association between intestinal parasitosis and availability of latrine among people living with HIV/AIDS in Ethiopia 
Author / Year

OR $(95 \% \mathrm{Cl})$

Weight

Missaye et al., 2013

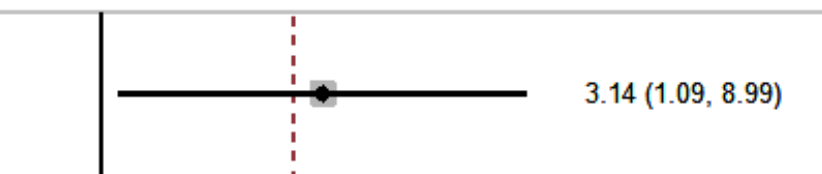

20.13

Shimelis et al., 2016

$1.23(0.69,2.19)$

27.20

Gedle et al., 2017

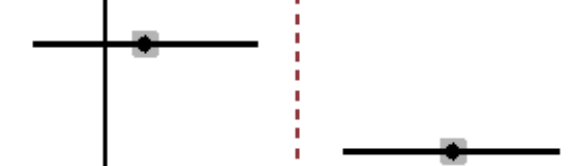

$5.98(3.41,10.49)$

27.42

Alemu et al., 2018

Overall $(l-$ squared $=80.1 \%, p=0.05)$

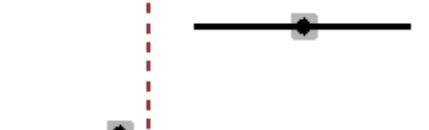

$2.31(1.14,4.71)$

25.25

$2.69(1.24,5.84)$

100.00

NOTE: Weights are from random effects analysis

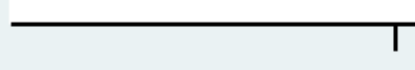

1

10

\section{Figure 8}

Forest plot showing pooled odds ratio for the association between intestinal parasitosis and presence of animal in home among people living with HIV/AIDS in Ethiopia

\section{Supplementary Files}

This is a list of supplementary files associated with this preprint. Click to download.

- suplementaryfile1.xIsx 